\title{
Reciprocity, Collective Action, and Community Policing
}

\author{
Dan M. Kahan $\dagger$
}

This Article has two goals. The first is to develop a theoretical framework for evaluating different techniques for policing street crime. The second is to highlight the explanatory and prescriptive power of a particular theory of social norms and law.

Recent years have witnessed the emergence of a diverse array of crime-fighting strategies-from "order maintenance" policing to churchpolice alliances to highly participatory forms of law enforcement. These innovations arguably deserve a significant share of the credit for the remarkable drop in crime during the last decade. They also speak to a dramatic reorientation in the politics of law enforcement: for decades a weapon by which dominant groups safeguarded their preeminence, streetlevel policing is now being recast by traditionally marginalized groups as a tool for revitalizing community life in the inner city. ${ }^{1}$

But the proponents of the "New Community Policing" have so far failed to identify a single theory of crime control that is comparable in parsimony and prescriptive richness to the rational-actor model that animates traditional policing strategies. The absence of such a theory threatens to impede the New Cominnnity Policing by making its claims of efficacy less credible and its diverse strategies less amenable to comparison with one another.

Almost contemporaneously with the development of the New Community Policing, the legal academy has witnessed the emergence of a sustained challenge to the conventional rational-actor theory that guides law and economics. This program features a diverse array of behavioral phenomena, often referred to generically as "social norms," drawn from

Copyright $\odot 2002$ California Law Review, Inc. California Law Review, lnc. (CLR) is a California nonprofit corporation. CLR and the authors are solely responsible for the content of their publications.

$\dagger$ Professor, Yale Law School. The ideas and research reflected in this paper stem from my involvement in the MacArthur Foundation's Research Network on Norms and Preferences (http://www.umass.edu/preferen/). I also owe thanks to Neal Katyal for comments, and to Chrystiane Pereira for research assistance.

1. See generally Tracey L. Meares \& Dan M. Kahan, Urgent Times: Policing and Rights In INNER-City Communities (Beacon Press 1999); Debra Livingston, Police Discretion and the Quality of Life in Public Places: Courts, Communities, and the New Policing, 97 Colum. L. Rev. 551 (1997). 
social psychology, sociology, and experimental economics. The socialnorms movement has generated important new insights in a variety of legal domains. ${ }^{2}$ But much like the New Community Policing, the social-norms project has been constrained by the failure of its adherents to rally behind a single account that combines the virtues of relative simplicity, reliable empirical grounding, and widespread policy relevance. ${ }^{3}$

I believe the needs of both the New Community Policing and the lawand-social-norms project can be satisfied simultaneously through a theory of reciprocity and collective action. According to this theory, individuals in collective-action settings behave not like simple wealth maximizers but rather like moral and emotional reciprocators. If they perceive that others are contributing to the collective good in question, then honor, self-respect, honesty, and like dispositions motivate most individuals to contribute to that good as well, even if doing so is personally costly. If, in contrast, they perceive that most individuals are free riding, then pride and resentment will move most persons to withhold contributions-and even to retaliate, if they can, against perceived shirkers-notwithstanding significant material incentives to do otherwise. This simple behavioral dynamic is supported by a wealth of empirical social science data. ${ }^{4}$ It also turns out to have immensely broad policy significance: tax collection, the siting of noxiouswaste facilities, and the assignment of intellectual property rights, for example, are all areas of regulation in which reciprocity dynamics can be harnessed to promote the public good.

Street-level policing turns out to be another. The extent of street criminality is shaped, I will try to show, by the success of citizens in negotiating three interlocking collective-action problems: one between individuals generally, who must decide whether to contribute to the collective good of respect for one another's persons and property or instead to engage in opportunistic acts of predation; one between neighbors, who must decide whether to contribute to the collective good of community self-policing or instead to turn a blind eye toward the problems of others and attend only to their own security; and one between community residents and police, who must decide whether to contribute to the collective good of cooperation and

2. See, e.g., Robert C. Ellickson, Order Without law: How Neighbors Settle Disputes (1991) (property law); ERIC POSNER, LAW AND Social NoRms (2001) (family law, contract law, criminal law); Richard H. Pildes, When Rights Are Not Trumps: Social Meanings, Expressive Harms, and Constitutionalism, 27 J. LEGAL STud. 725 (1998) (constitutional law); Richard McAdams, Cooperation and Conflict: The Economics of Group Status Production and Race Discrimination, 108 HARV. L. Rev. 1003 (1995) (discrimination law); Ellen Waldman, Identifying the Role of Social Norms in Mediation: A Multiple Model Approach, 48 HASTINGS L.J. 703 (1997) (altemative dispute resolution).

3. See generally Robert C. Ellickson, Law and Economics Discovers Social Norms, 27 J. LEGAL STud. 537 (1998).

4. See Dan M. Kahan, The Logic of Reciprocity: A Theory of Collective Action and Law ch.2, $11-40$ (2002) (unpublished manuscript, on file with author). 
respect or instead to approach one another with suspicion and animosity. As in other collective-action settings, individuals within these environments behave like moral and ennotional reciprocators, contributing or not contributing to the collective good depending on whether they perceive others to be contributing.

The success of competing street-level policing techniques thus turns on how well each promotes reciprocal cooperation across these three settings. Founded on the assumption that individuals respond only to incentives, the traditional deterrence model of law enforcement does little to nurture the perception of reciprocal cooperation. Indeed, it breeds reciprocal noncooperation by implying that most citizens are not inclined to respect one another's rights voluntarily, by displacing spontaneous community self-policing, and by heighteming tension between community residents and the police. Most of the New Community Policing strategies, in contrast, do foster reciprocal cooperation across one or more of these collective-action settings. Nevertheless, most of these strategies also have at least the potential to disrupt reciprocal cooperation within one or more of the collective-action settings as well, constraining their effectiveness. The technique most likely to promote reciprocal cooperation across all the relevant domains, my analysis will suggest, is a highly decentralized and participatory one that integrates private citizens into many law-enforcement functions.

My analysis will unfold in three parts. Part I introduces the reciprocity theory, which I will describe primarily in opposition to the conventional logic or theory of collective action founded on the rational-actor model. Part II uses the logic of reciprocity to explain the inadequacies of the deterrence strategy of law enforcement associated with the conventional theory of collective action. Part III uses the reciprocity theory to evaluate a variety of alternative law-enforcement strategies associated with the New Community Policing.

\section{I}

\section{THE LOGIC OF RECIPROCITY}

Mancur Olson's The Logic of Collective Action ${ }^{5}$ for decades has supplied the dominant logic of public policy analysis. In this pioneering application of public-choice theory, Olson elegantly punctured the premiseshared by a diverse variety of political theories-that individuals can be expected to act consistently with the interest of the groups to which they belong. Absent externally imposed incentives, rational individuals, he argued, will rarely find it in their interest to contribute to goods that benefit the group as a whole, but rather will "free ride" on the contributions that

5. Mancur Olson, The logic of Collective Action (1965). 
other group members make. As a result, too few individuals will contribute sufficiently, and the well-being of the group will suffer. ${ }^{6}$ These are the assumptions that dominate policy analysis and ultimately public policy making across a host of regulatory domains-from tax collection to environmental law, from regulation of professions to regulation of the Internet.

But a growing body of empirical work, primarily in the fields of social psychology and experimental economics, suggests that these assumptions are wrong, or at least seriously incomplete. This research demonstrates that individuals who face collective-action problems do not invariably behave in the selfish and collectively self-defeating fashion predicted by the conventional view. On the contrary, most individuals can be counted on to make voluntary contributions to collective goods, so long as they are assured that others are prepared to do the same.

Considered in total, this research supports a distinctive theory of collective action. That theory, which I will call the "reciprocity theory," can be reduced to three key elements, each of which stands in opposition to a corresponding element of the conventional theory of collective action. ${ }^{8}$

Two Theories of Collective Action

\begin{tabular}{ll|l|}
\multicolumn{1}{c}{ Conventional Theory } \\
\cline { 2 - 3 } Agents & Rational wealth maximizers & Emotional/moral reciprocators \\
\cline { 2 - 3 } Collective Behavior & Unique Equilibrium & Multiple Equilibria \\
\cline { 2 - 3 } Regulatory Policy & Incentives & Trust \\
\cline { 2 - 3 } & &
\end{tabular}

The first pair of contrasting elements relates to the nature of individuals' utility functions. The conventional theory assumes that individuals in collective-action settings-ones that take the form of a standard prisoners' dilemma-behave like rational wealth maximizers. That is, they refuse to contribute to public goods and instead free ride on the contributions made by others, who, as rational wealth naximizers, also contribute nothing. The reciprocity model, in contrast, depicts individuals as moral and emotional

6. See id. at $1-2$.

7. For overviews, see Ernst Fehr \& Simon Gächter, Fairness and Retaliation: The Economics of Reciprocity, 14 J. ECON. PERSP. 159, 162 (Summer 2000); Ernst Fehr \& Simon Gächter, Reciprocity and Economics: The Economic Implications of Homo Reciprocans, 42 EUR. EcoN. REv. 845, 850 (1998); Armin Falk \& Urs Fischbacher, A Theory of Reciprocity 30 (July 2000) (unpublished manuscript, on file with author).

8. See generally Kahan, supra note 4, at ch.2, 13-40. 
reciprocators. ${ }^{9}$ If individuals perceive that others are contributing to a collective good, then honor, honesty, public spiritedness and like dispositions motivate them to do the same. If, in contrast, they perceive that others are not contributing their fair share, then resentment and pride move them to withhold their contributions as well.

A vast body of social-science evidence supports the reciprocity theory's view of individual motivations. ${ }^{10}$ Much of it is experimental in nature. For example, "public goods" experiments-laboratory constructs designed to simulate collective-action problems-have consistently shown that the willingness of individuals to make costly contributions to collective goods depends largely on their perception of the willingness of others to do the same. ${ }^{11}$ Empirical studies of real-world behavior corroborate this finding. Individuals have been shown, for example, to reciprocate the disposition of others to give (or not) to charity, ${ }^{12}$ to refrain (or not) from littering, ${ }^{13}$ and to wait their turn (or not) in lines. ${ }^{14}$ Indeed, individuals behave like reciprocators even in markets: econometric and other forms of field research suggest that when firms compensate their workers more generously, workers reciprocate by voluntarily working harder. ${ }^{15}$

9. A brief explanation of my use of the terms "moral" and "emotional" may be in order. "Moral" refers to the nonmonetary quality of the reciprocal states of affairs that individuals pursue; that is, individuals view contributing to collective goods when others are contributing, and withholding their contributions and even retaliating when others are not contributing, as morally appropriate courses of action, even when costly. Of course, whether they are right, morally speaking, to regard their duties to contribute as conditional in this sense is a separate issue, one that I will not address. "Emotional" refers, very generally, to the subjective quality of the motive to behave like a reciprocator. Individuals are likely to experience reciprocal motivations as emotional states-of, say, pride or resentment-broadly rather than as nonaffective, calculative assessments of their interests of the sort that we associate with purely instrumental reasoning. My analysis does not depend, though, on any particular theory of the form that reciprocal motivations take as a subjective matter, it only requires that (most) individuals, for whatever reason, tend to behave like reciprocators within collective-action settings.

10. See Kahan, supra note 4, at ch.2, 13-23.

11. See Falk \& Fischbacher, supra note 7.

12. See Peter H. Reingen, Test of a List Procedure for Inducing Compliance with a Request to Donate Money, 67 J. APPLIED Psychol. 110 (1982); see also RoberT B. Cialdini, INFLUENCE: SCIENCE AND PRACTICE 96-97 (3d ed. 1993) (describing techniques used to create impressions of widespread charitable giving).

13. See Elliot Aronson, The Social Animal 29-30 (7th ed. 1995); Robert B. Cialdini et al., $A$ Focus Theory of Normative Conduct: Recycling the Concept of Norms to Reduce Littering in Public Places, 58 J. Personality \& Soc. Psychol. 1015 (1990).

14. See Stanley Milgram et al., Response to Intrusion into Waiting Lines, 51 J. Personality \& Soc. Psychol. 683 (1986); Bernd H. Schmitt et al., Intrusions into Waiting Lines: Does the Queue Constitute a Social System?, 63 J. Personality \& Soc. Psychol. 806 (1992).

15. See George A. Akerlof, Labor Contracts as Partial Gift Exchange, 47 Q.J. Econ. 543 (1982); WILLIAM T. DICKENS \& LAWRENCE F. KaTZ, INTER-INDUSTRY WAGE DIFFerenCES AND TheORIES OF Wage Determination, 25-26 (Nat'l Bureau of Econ. Research, Working Paper No. 2271, 1987); Lawrence F. Katz \& Lawrence H. Summers, Industry Rents: Evidence and Implications, in BrookINGS PAPERS ON ECONOMC ACTIVITX: MicroeCONOMICS 209 (Martin Neal Baily \& Clifford Winston eds., 1989). See generally EFFICIENCY WAGE MODELS of THE LABOR MARKET (George A. Akerlof \& Janet L. Yellen eds., 1986). In this example, I am assuming that the reciprocating agents are the individual and the firm. One might posit that worker-output norms evolve spontaneously and more or less 
The second pair of contrasts concerns collective behavior. In typical collective-action settings, the conventional theory treats defection or free riding as the dominant strategy for every individual. Accordingly, that theory predicts a single collective behavioral equilibrium: universal noncooperation.

Under the reciprocity theory, in contrast, there can be multiple behavioral equilibria. For reciprocators, there is no dominant strategy: they prefer to contribute if they believe others are inclined to contribute, but to free ride if they believe that others are inclined to free ride. Accordingly, behavior in collective-action settings tends to feed on itself. If, for whatever reason, some individuals conclude that those around them are inclined to contribute, they will respond by contributing in kind, prompting still others to contribute, and so forth and so on until a highly cooperative state of affairs takes root. But if some individuals conclude that others are free riding, then they will respond by free riding too, spurring others to do the same, and so forth and so on until a condition of mass noncooperation becomes the norm. ${ }^{16}$

This dynamic also has been empirically documented. In multiround public-good experiments, for example, contribution levels tend to migrate steadily toward or away from the social optimum depending on whether subjects behaved relatively cooperatively or noncooperatively early on. ${ }^{17}$ Scholars have also documented that the incidence of littering, recycling, smoking in public, safe sex, and other types of behavior that affect collective welfare are likewise subject to feedback effects and multiple equilibria-generating dramatic variations in their incidence across space and over time. ${ }^{18}$

The third contrast has to do with policy prescriptions. The conventional theory sees incentives as the solution to collective-action problems: because rational wealth maximizers caunot be counted on to contribute to public goods, they must be prodded to do so with either

randomly as workers simply conform their efforts to those of their coworkers. See generally STEPHEN R. G. JONES, THE ECONOMICS OF CONFORMISM (1984) (developing such a theory). The weakness of this account, however, is that it doesn't explain the correllation between variance in output levels and (noncompensating) wage differentials across firms. A theory that treats workers as reciprocating gratuitously generous wages with spontaneously higher levels of effort does explain this fact.

16. See Kahan, supra note 4, at 22-24.

17. See generally Falk \& Fischbacher, supra note 7, at 29-31; John O. Ledyard, Public Goods: A Survey of Experimental Research, in THE HANDBOOK OF EXPERIMENTAL ECONOMICS 111, 139-40 (John H. Kagel \& Alvin E. Roth eds., 1995).

18. See, e.g., Robert Cooter, Normative Failure Theory of Law, 82 CoRNELI L. REv. 947, 976-77 (1997) (smoking and compliance with "pooper scooper" laws); Timur Kuran \& Cass R. Sunstein, Availability Cascades and Risk Regulation, 51 STAN. L. REV. 683, 688-89, 746 (1999) (safe sex, smoking, enviornmental concerns); Cass R. Sunstein, On the Expressive Function of Law, 144 U. PA. L. REv. 2021, 2032-36 (1996) (smoking, safe sex, firearm use and various other forms of risk-creating behavior). 
rewards or punishments that bring their individual interests into alignment with their collective ones.

The reciprocity theory suggests an alternative policy: the promotion of trust. If individuals can be made to believe that others are mclined to contribute to public goods, then individuals can be induced to contribute as well, even without recourse to incentives. When permitted to communicate, for example, subjects in multiround public-goods experiments tend to assure one another that they will contribute rather than free ride. Although unenforceable, such assurances do in fact prompt larger contributions, which subjects quickly put toward the social optimum as they observe others doing the same. ${ }^{19}$ Face-to-face assurance-giving, in sum, generates trust, which in turn generates reciprocal cooperation.

Indeed, field and laboratory research suggests that incentives, far from solving collective-action problems, can sometimes actually magnify them by dissipating trust. ${ }^{20}$ The simple existence of an incentive scheme can be seen as a cue that other individuals are not inclined to cooperate voluntarily: if they were, incentives would be unnecessary. This inference can trigger a reciprocal disposition to withhold voluntary cooperation, thereby undercutting, if not wholly displacing, the force of the incentive. In addition, the existence of incentives can mask voluntary contributions to public goods, thereby diluting the power of such contributions to trigger reciprocal cooperation. ${ }^{21}$ Similarly, incentives can crowd out dispositions such as altruism by extinguishing the opportunity of individuals to demonstrate (to themselves and to others) that they are willing to sacrifice material gain for the public good. ${ }^{22}$ And if for any of these reasons, the advent of a material incentive induces even a few individuals to contribute less to a public good, reciprocity dynamics will induce still others to contribute less, thereby inducing others to do the same, and so forth and so on. The result will be a new, noncooperative equilibrium-one that is likely to be impervious to the subsequent removal of material incentives insofar as it is sustained by self-reinforcing expectations of noncooperation. ${ }^{23}$

The reciprocity theory has important policy implications. Current taxcollection policy, for example, reflects the assumption that citizens, as

19. See Ledyard, supra note 17, at 156-68; Elinor Ostrom, Collective Action and the Evolution of Social Norms, 14 J. ECON. PERSP. 137, 146 (2000)

20. See, e.g., Richard M. Titmuss, The Gift Relationship: From Human Blood to Social PoLICY (1971) (finding that incentives suppress donation of blood); Uri Gneezy \& Aldo Rustichimi, $A$ Fine Is a Price, 29 J. LEGAL. STUD. 1 (2000) (finding that fine increased rather than decreased abuse of day care center rules by parents); Uri Gneezy \& Aldo Rustichini, Pay Enough or Don't Pay at All (Apr. 1999) (unpublished manuscript, on file with author) (finding that incentives decreased rather than increased performance of individuals soliciting charitable donations).

21. See Kahan, supra note 4, at 30-33.

22. See Bruno S. Frey, Not Just for the Money: An Economic Theory of Personal Motivation (1997).

23. See Kahan, supra note 4, at 30-33. 
rational wealth maximizers, will cheat on their taxes whenever they can get away with it, and that a salient threat of punishment is therefore the best means of assuring widespread compliance. The truth, however, is that most taxpayers behave like moral and emotional reciprocators: in deciding whether to pay their taxes in full, they are more influenced by their perception that others are or are not complying than they are by the material costs and benefits of evasion. ${ }^{24}$ Consistent with the emphasis that the reciprocity theory puts on trust, simply informing individuals that tax-compliance rates in the United States are admirably high-as they are - turns out to be a more effective, not to mention a substantially less expensive, means of bolstering compliance than does increasing the expected penalty for tax fraud. Indeed, consistent with the anxiety that the reciprocity theory has about the trust-dissipating potential of incentives, high-profile tax-enforcement campaigns have been shown to diminish the commitment of individuals to comply with the tax law because they imply that evasion is in fact widespread. $^{25}$

The conventional theory exerts a similarly distorting effect over the placement of noxious facilities. It is convenient-indeed, essential-for everyone that waste-treatment centers, prisons, airports, and the like exist somewhere, yet it is convenient for no one to have such facilities located in their neighborhoods. Accordingly, the conventional theory counsels that the residents of host communities be offered financial compensation and other inducements. However, incentives of this sort, far from diminishing opposition to the siting of noxious facilities, have been shown in many cases to accentuate it. ${ }^{26}$ The reason is that individuals, in this collectiveaction setting as in others, behave like reciprocators. They tend to resist noxious-facility siting when, and to the extent that, they believe that other communities are not accepting burdens of like significance. When they feel this way, the offer of cold cash as an exchange magnifies the sense of indignation and resentment that putative host communities feel. Much more effective is a program of bottom-up negotiations in which putative hosts are solicited to accept noxious facilities on terms of their choosing (including the acceptance of limited in-kind burdens by other communities)a process that engenders trust between putative host communities and regulators in much the same way that face-to-face discussions do in publicgoods games. ${ }^{27}$

24. See Dan M. Kahan, Trust, Collective Action, and Law, 81 B.U. L. Rev. 333, 341-42.

25. See id. at 342 . See generally Kahan, supra note 4, ch.3.

26. See FREY, supra note 22, at 69-75; Howard Kunreuther et al., Public Attitudes Toward Siting a High-Level Nuclear Waste Repository in Nevada, 10 RisK ANalysis 469, 480 (1990). Howard Kunreuther \& Doug Easterling, The Role of Compensation in Siting Hazardous Facilities, 15 J. PoL'y ANALYSIS \& MGMT. 601, 606-07 (1996).

27. See Kahan, supra note 4, ch.4 at 3-17. 
Or, as a final example, consider scientific and technological innovation. The conventional theory again resorts to incentives, in the form of intellectual property rights, to induce the creation of inventions that benefit society as a whole. Yet a growing body of work has documented that within certain fields, including basic scientific research and many types of computer software development, individuals will reciprocate spontaneous contributions to a collaborative inventive enterprise with like contributions of their own, generating innovations that rival and often surpass the quality of those generated by proprietary modes of production. ${ }^{28}$ Where this is so, the deadweight losses and admimstrative costs inevitably associated with intellectual property rights need not be endured to secure the public benefits of invention. Indeed, university scientists, computer hackers, and other reciprocal producers tend to suspend the free exchange of ideas once they come to suspect that those with whom they are collaborating are intent on appropriating the commercial value of those innovations for themselves. ${ }^{29}$ Overextending intellectual property rights in these domains, then, could actually inhibit invention rather than stimulate it. Blinded, here as elsewhere, by the conventional logic of collective action, there is a distinct risk that the law will vitiate the potential efficiency of reciprocity.

\section{II}

\section{ReCIPROCITY AND the Illogic of THE CONVENTIONAL DeterRence} STRATEGY

The logic of reciprocity exposes the illogic of a host of policies that rest on the assumptions of the conventional theory of collective action. The traditional approach to street-level policing is another such policy.

The conventional theory sees crime prevention as just another collective-action problem. As a society, we are all better off when we universally refrain from theft and like forms of predation. But as individuals, each one of us is better off free riding on whatever restraint our neighbors display while engaging in as much looting and pillaging as possible. Public order is, in short, a public good, one that will always be in short supply if individuals are left to their own devices. If this is how one thinks of the problem of crime, then the obvious solution is to create incentives that bring individual interests into alignment with collective ones. Hence, one solution is to threaten punishment for those who break the law.

The conventional theory of collective action thus naturally gives rise to the law-enforcement strategy of deterrence, which can be neatly

28. See, e.g., Yochai Benkler, Coase's Penguin, or, Linux and the Nature of the Firm 112 YalE L.J. (forthcoming 2003); Arti Kaur Rai, Regulating Scientific Research: Intellectual Property Rights and the Normis of Science, 94 Nw. U. L. REv. 77 (1999).

29. See Benkler, supra note 28, at 36-37. 
formalized in terms first proposed by Bentham ${ }^{30}$ and later refined by Becker. ${ }^{31}$ On this theory, individuals, as rational wealth maximizers, commit crime when the gain, $G$, is greater than the expected punishment, which is equal to the product of the specified penalty, $P$, and the certainty, $C$, that it will be imposed. Thus, crime is deterred when $P \times C>G .^{32}$

Of course, it is efficient or collectively wealth-maximizing to deter crime only if the social cost of $P \times C$ is less than the social losses associated with the crimes that $P \times C$ deters. Accordingly, society must be attentive to the cost of various $P \times C$ pairings. This attentiveness generally favors severity over certainty: maintaining a high likelihood of detection and conviction $(C)$ requires a continuing investment in police officers, judges, prosecutors, and public defenders, and so on, whereas a high level of punishment $(P)$, assuming it deters and thus does not have to be imposed all that often, will not cost much to implement and will allow society to economize on the various components of law enforcement. ${ }^{33}$

This turns out to be a fair summary of the guiding philosophy of American criminal law enforcement in the last twenty-five years, the results of which do little to vindicate the wisdom of the conventional theory. Variance in the severity of punishment has consistently been shown to explain little, if any, of the variance in incidences of crime across place and time. ${ }^{34}$ Certainty of conviction makes a difference, although a relatively small one..$^{35}$ As the federal government and the states steadily ratcheted up the severity of punishment from the late 1970s to the early 1990s, crime rates held constant. In the case of homicide, crime rates even increased. ${ }^{36}$

What matters much more than the expected penalty for crime is a diverse collection of social conditions and public attitudes often featured in accounts that link crime to social norms. Thus, communities characterized by low social organization, as measured by the quality and vitality of

30. See Jeremy Bentham, An Introduction to the Principles of Morals and Legislation, reprinted in THE UTILITARIANS (1961).

31. See Gary S. Becker, Crime and Punishment: An Economic Approach, 76 J. Pol. EcoN. 169 (1968).

32. See id.

33. See id.; Richard A. Posner, An Economic Theory of the Criminal Law, 85 Colum. L. REv. 1193, 1206-07 (1985).

34. See generally Daniel Nagin, Criminal Deterrence Research at the Outset of the Twenty-First Century, in 23 CRIME \& Just. 1, 4-12 (Michael Tonry ed., 1998) [hereinafter Nagin, Criminal Deterrence]. See also Daniel Nagin, Integrating Celerity, Impulsivity, and Extralegal Sanction Threats into a Model of General Deterrence: Theory and Evidence 3, 5 (Jan. 15, 2000) (unpublished manuscript, on file with author).

35. See generally Nagin, Criminal Deterrence, supra note 34, at 1.

36. See Jeffrey Fagan \& Tracey L. Meares, Punishment, Deterrence and Social Control: The Paradox of Punishment in Minority Communities 1-2 (Colum. L. Sch. Pub'1 L. \& Legal Theory Working Paper No. 10, Mar. 25, 2000). Crime did start to decline around the middle of the 1990s, but only after New York and other cities moved away from severe punishment to other law-enforcement strategies. Dan M. Kahan, Social Influence, Social Meaning, and Deterrence, 83 VA. L. REV. 349, 36869 (1997). 
voluntary civic associations, tend to experience more crime. ${ }^{37}$ So do ones in which institutions lack legitimacy, as measured by the willingness of individuals to view the decisions of lawmakers and law enforcers as intrinsically entitled to deference. ${ }^{38}$ Social influence-the tendency of individuals to conform their behavior to those around them-also contributes to the incidence of crime, generating multiple crime-rate equilibria independent of the expected penalty for lawbreaking. ${ }^{39}$

Where social norms are conducive to criminality, many individuals will break the law notwithstanding very severe penalties. Indeed, there is reason to believe that severe penalties can deleteriously affect norms: massive incarceration, particularly when concentrated on minority, inner-city communities, disrupts social organization and taxes institutional legitimacy.$^{40}$ Because it results in lengthening incarceration for many citizens, the conventional deterrence strategy turus out not to be particularly cost-effective after all, not to mention morally problematic on a host of nonutilitarian grounds.

The contribution that diverse social norms make to street criminality, and the potentially perverse effect of the classical deterrence strategy on social norms, can be systematized and refined by the reciprocity theory. The diverse psychological and social factors that predict crime suggest that reciprocity dynamics operate within not just one but rather three interlocking collective-action dynamics. The first involves the conflict that exists between the interests of society in law-abiding behavior and the interests of individuals in committing crimes. This is the "public order" collectiveaction problem that occupies the attention of the conventional theory. The contribution that social influence makes to crimes suggests that in this collective-action setting as in others, many individuals behave like reciprocators; that is, they tend to respect the security of others in their persons and property in proportion to their perception that others are doing the same. ${ }^{41}$

The second collective-action problem focuses on the collective good of "community self-policing." Neighborhoods can do a lot to protect themselves from crimes. Individuals can watch over one another's residences. People can take an interest in the activities of one another's children, alerting neighboring parents when they see neighborhood kids veering into trouble or even making an effort to steer them out of trouble themselves. ${ }^{42}$

37. See Robert J. Sampson et al., Neighborhoods and Violent Crime: A Multilevel Study of Collective Efficacy, 277 Scr. 918 (1997).

38. See Tom R. Tyler, IVhy People Obey the LaW (1990).

39. See Kahan, supra note 36 , at 359-60.

40. See Fagan \& Meares, supra note 36.

41. See Kahan, supra note 36 .

42. See generally Elijah Anderson, Streetwise: Race, Class, and Change in an URean Community 3,70-77 (1990) (discussing role of generalized youth supervision, and consequence of its deterioration, in containing crime in inner city); Tracey L. Meares, Social Organization and Drug Law Enforcement, 35 AM. CRIM. L. REv. 191, 204, 207 (1998) (surveying empirical evidence). 
Individuals can make their communities safer just by maintaining a conspicuous presence on its sidewalks and streets, especially at night. ${ }^{43}$ The community benefits collectively when everyone engages in these activities. Yet it remains in the interest of each individual to free ride on the willingness of others to monitor, mentor, and be conspicuous while attending exclusively to his or her own private business, especially where such activities can expose those who engage $\mathrm{m}$ them to inconvenience or risk. ${ }^{44}$

The impact of social organization on crime suggests that reciprocity dynamics also play a large role in determining how citizens respond to the community self-policing dilemma. Where citizens regularly encounter each other in voluntary associations-from churches to PTAs, from neighborhood improvement organizations to local chambers of commerce-they are much more likely to observe other individuals contributing to common endeavors and thereafter to reciprocate by doing the same. In atomized communities, in contrast, individuals are necessarily thrown back on their own devices; they are much less likely to see examples of public-spirited behavior and thus are much less likely to fall into self-reinforcing patterns of common regard and concern. ${ }^{45}$

The third collective-action problem hinges on the public good of "citizen-police cooperation." The police obviously benefit when citizens supply them with information about crime ${ }^{46}$ Citizens benefit, too, when the police attend diligently to their needs and treat them with respect in daily encounters. Yet it will often be in the individual interest of citizens and police officers not to behave in these ways. When individuals report crimes, they expose themselves at a minimum to inconvenience, and possibly worse-the risk of violent retaliation at the hands of those they are reporting. ${ }^{47}$ Where the law is perceived to be illegitimate, or enforcers arbitrary or biased, individuals who cooperate with the police are likely to experience personal guilt or be stigmatized by other members of the community. ${ }^{48}$ For their part, the police might perceive that civilized and polite

43. See Jane Jacobs, The Death and Life of Great American Cities 29-35 (1961).

44. By characterizing "community self-policing" as a "collective good," I mean to refer only to the feature of nonexcludability that makes a state of general neighborhood vigilance available to any individual who lives in the neighborhood, regardless of whether that individual contributes to it or not. See generally Russell Hardin, Collective Action 19-20 (1982). Obviously, the value of this "good," and its potential conflict with other goods such as individual privacy, are open to dispute. I will assume for purposes of my analysis, though, that community self-policing is in fact normatively desirable.

45. See Meares, supra note 42, at 197-98; Robert D. Putnam, Bowling Alone: The Collapse and Revival of American CoMmunity (2000).

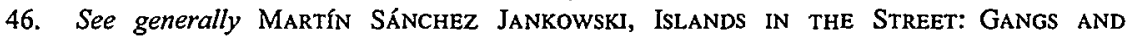
AMERICAN URBAN SOCIETY 193, 202-03 (I991) (arguing that cooperation between community and police is both necessary and sufficient to destroy viability of criminal gangs).

47. See George Akerlof \& Janet L. Yellen, Gang Behavior, Law Enforcement and Community Values, in Values and Public Policy 180 (Henry J. Aaron et al. eds., 1994).

48. See id. at 181-82; ANDERSON, supra note 42, at 190, I95-96, 205. 
engagement with private citizens sometimes makes it harder for them to obtain information necessary to solve crimes, or cven exposes them to physical risks. ${ }^{49}$ They might also prefer to avoid the risks and inconveniences associated with their duty to safeguard private citizens from crime.

Reciprocity dynamics figure largely in a community's capacity to negotiate this collective-action problem as well. Citizens are more disposed to cooperate with police when institutions enjoy a high level of legitimacy. The perceived legitimacy of an institution, it has been shown, depends largely on whether citizens perceive that they are receiving fair and respectful treatment by police and other decision makers. ${ }^{50}$ In effect, citizens reciprocate respectful treatment with cooperation and obedience and disrespectful treatment with resistance-not only to the directives of individual decision makers but to the commands of the law more generally. ${ }^{51}$ Likewise, how compliant or resistant citizens are perceived to be no doubt influences the willingness of the police to interact with them in a civil rather than a coercive fashion and to otherwise respond attentively to their needs. ${ }^{52}$

The inefficacy of the conventional deterrence strategy is a consequence of the effects it has on inhibiting reciprocal cooperation within these three collective-action settings. Considered in isolation, the effect of the conventional deterrence strategy on the public-order collective-action problem is ambiguous. It is implausible to think that the threat of punishment has no restraining influence, particularly on individuals who for whatever reason are not restrained by socially inculcated dispositions such as shame and guilt. ${ }^{53}$ At the same time, as the effect of high-profile tax auditing campaigus suggests, it seems reasonable to infer that conspicuously severe penalties for street crimes might sometimes indicate that criminality is in fact widespread. This inference, due to the effects of reciprocity on community dynamics, would dilute the motivation of some individuals to respect the rights of others.

But even assuming that its effect on the public-order dilemma is positive on the whole, the conventional deterrence strategy clearly has a negative effect on the community-self-policing and the citizen-policecooperation dilemmas. Public law enforcement and community

49. See Tom R. Tyler, Trust and Law Abidingness: A Proactive Model of Social Regulation, 81 B.U. L. REv. 361, 368-69 (2001) (maintaining control of potentially dangerous situations as means of self-protection).

50. See id. at $367-68,376-78,385-86$.

51. See id. at 389.

52. See ANDERSON, supra note 42, at 202-03; cf. Tyler, supra note 49, at 369,384 (noting potential for displays of aggression to feed on each other in encounters between police and citizens).

53. Cf. Wilbur J. Scott \& Harold G. Grasmick, Deterrence and Income Tax Cheating: Testing Interaction Hypotheses in Utilitarian Theories, 17 J. AppLIEd BEHAV. ScI. 395 (1981) (concluding that effect of perceived penalty for lawbreaking influences only those who are not motivated to comply by internalitzation of norms). 
self-policing are, economically speaking, substitutes for one another. That is, the more a community has of one, the less it needs of the other in order to hold crime in check. Accordingly, as the state purports to assume a larger share of the deterrence burden through adoption of severe penalties, it actually undermines individuals' incentive to collaborate with each other to safeguard their communities from crime, at least to an extent. ${ }^{54}$ As public enforcement suppresses community self-policing in this way, citizens have less occasion to observe one another making conspicuous contributions to the safeguarding of their own communities from crime. And having less exposure to monitoring, mentoring, and creating a street presence, individuals, as reciprocators, become even less inclined to engage in such behavior themselves. ${ }^{55}$ In effect, severe penalties crowd out and mask the disposition of individuals to contribute to community self-policing, making severe penalties all the more necessary to compensate.

Severe penalties also discourage individuals from cooperating with the police. Such penalties increase the likelihood that the targets of reporting will retaliate. Indeed, if severe penalties are used to compensate for a low certainty of detection and conviction, most individuals will perceive that the likelihood of obtaining any benefit from reporting is largely futile anyway. ${ }^{56}$ In addition, particularly in minority communities, already burdened with high incarceration rates, severe penalties help to construct the perception that the system is unjust. ${ }^{57}$ Accordingly, it is when the state penalizes criminal wrongdoing severely that individuals are most likely to be inhibited from cooperating out of guilt or fear of being branded a collaborator. Confronted with an uncooperative citizenry, the police will likely respond by engaging in heavy-handed enforcement, either to compensate for the dearth of private tips, to protect their own security, or simply to vent their frustration. This behavior by the police will in turn provoke citizens to be even less cooperative. Deprived of the benefits associated with community support, which turns out to be the most potent weapon for combating gangs, ${ }^{58}$ the state will be forced to resort to even more severe

54. See generally Omri Ben-Shahar \& Alon Harel, Blaming the Victim: Optimal Incentives for Private Precautions Against Crime, 11 J.L. Econ. \& ORG. 434 (1995); Keith Hylton, Optimal Law Enforcement and Victim Precaution, 27 RAND J. EcoN. 197 (1996); Tomas J. Philipson \& Richard A. Posner, The Economic Epidemiology of Crime, 39 J.L. \& EcoN. 405 (1996). In truth, the assumption of perfect substitutability is an oversimplification. For one thing, there are reasons to believe that particular types of public and private law enforcement that have equivalent effects on the expected penalty for lawbreaking are nevertheless inequivalent in their deterrent effects because of the divergent information they convey about the extent of criminality in the community and about public attitudes toward crime. See Kahan, supra note 36, at 386-89. For purposes of my analysis here, though, I believe the substitutability thesis captures enough truth to be useful.

55. See ANDERSON, supra note 42, at 57-58.

56. See Kahan, supra note 36 , at 381.

57. See Meares, supra note 42, at 213-14.

58. See JANKOIVSKI, supra note 46, at 20!-03. 
penalties, thereby aggravating the citizen-police cooperation problem all the more..$^{59}$

Ultimately, the negative effect of the classical deterrence strategy on the community-self-policmg and citizen-police-cooperation dilemmas vitiates whatever positive effect the strategy might have had on the publicorder dilemma. Convinced that those in the community will not do anything to stop crime, and resentful of a heavy-handed state, individuals are likely to respond by engaging in more lawbreaking, which then feeds on itself as the spectacle of rampant criminality induces others to abandon whatever compunction they might have felt not to prey on their neighbors. The result is a self-sustaining high-crime-rate equilibrium, fueled by distrust and various forms of negative reciprocity.

III

\section{ReCIPROCITY AND The Logic OF COMMUNity Policing}

The strategies that make up the New Community Policing explicitly attend to social norms. Indeed, it is the asserted positive effect of these strategies on one or more social norms that is said to account for the advantages of the New Community Policing. The reciprocity theory fortifies this claim. Whereas the conventional deterrence strategy disrupts reciprocal cooperation within the three collective-action dilemmas that construct the problem of street crime, the various strategies associated with the New Community Policing accentuate reciprocal cooperation by fostering trust within these settings.

This analysis can also be used to compare New Community Policing strategies to one another. All of them, 1 will try to show, promote reciprocal cooperation within the relevant collective-action settings, but some of them at least potentially inhibit it in one or more of them as well. I will examine three New Community Policing strategies: order-maintenance policing, church-police collaboration, and selective privatization.

\section{A. Order-Maintenance Policing}

The most famous, and most controversial, technique associated with the New Community Policing is the strict enforcement of "public order" laws. Under the "order maintenance" strategy, police invest fewer resources in deterring serious crimes such as murder, armed robbery, and burglary, and more in attacking less serious forms of misconduct, such as vandalism, aggressive panhandling, prostitution, and public drunkenness. ${ }^{60}$

59. See Akerlof \& Yellen, supra note 47, at 192-93, 195.

60. See Livingston, supra note 1 . 
This strategy is credited by some criminologists with dramatically reducing crime in New York City, among other places. ${ }^{61}$

First suggested by Wilson and Kelling in their famous Broken Windows essay, ${ }^{62}$ the theory behind order-maintenance policing is that visible disorder undermines law-abiding norms. Public drunkenness, prostitution, aggressive panhandling, and the like are cues that a commnnity is unable or unwilling to enforce basic norms of civility. A commnnity that cannot do that, individuals infer, is likely to be powerless to prevent more serious crimes. Through the mechanism of social influence, many individuals who draw this inference will themselves engage in crime, reinforcing the disposition of others to do the same. Committed law-abiders, if they have the resources, are likely to leave a neighborhood that is pervaded by disorder. Their departure increases the concentration of potential lawbreakers, thereby multiplying their interactions with each other and accentuating their mutually reinforcing propensities to engage in crimes. Law-abiders who stick it out, moreover, are more likely to avoid the streets, where their simple presence would otherwise deter crime. They are also more likely to distrust their neighbors, and thus less likely to join leagues with them to monitor their community for sigus of trouble. ${ }^{63}$

Order-maintenance policing reverses these effects. When citizens obey norms of orderliness, and when authorities visibly respond to those who do not, onlookers see that the community is intolerant of criminality. This message counteracts the inferences that provoke the self-reinforcing decisions of potential lawbreakers to engage in more serious crimes. It also reassures law-abiders, inducing them to resume individual and collective forms of neighborly monitoring. In this way, the perception of obedience quickly becomes reality, and at a fraction of the cost of the severe penalties associated with the classic strategy of deterrence. ${ }^{64}$

Viewed through the lens of the reciprocity theory, order-maintenance policing can be seen as having directly positive effects on the public-order and community-self-policing dilemmas. The appearance of order implies broader obedience to law, which individuals reciprocate by behaving more

61. See George L. Kelling \& Catherine M. Coles, Fixing Broken Windows: Restoring ORder ANd Reducing Crime in Our Communities (1996). But see Jeffrey Fagan \& Garth Davies, Street Stops and Broken Windows: Terry, Race, and Disorder in New York City, 28 FordHAM URB. L.J. 457 (2000).

62. See James Q. Wilson \& George L. Kelling, Broken Windows, ATlanTic MonThLY, Mar. 1982 , at 29.

63. See Kahan, supra note 36, at 370. See generally Wesley G. SKogan, Disorder and Decline: Crime and the Spiral, of Decay in American Neighborhoods (1990) (presenting empirical evidence in support of "broken window" hypothesis).

64. See Kahan, supra note 36, at 370-71. See generally Robert J. Sampson \& Jacqueline Cohen, Deterrent Effects of the Police on Crime: A Replication and Theoretical Extension, 22 LAw \& Soc'Y REv. 163 (1988) (presenting empirical evidence linking order-maintenance policing with reduced crime). 
obediently themselves. By stanching the flight of law-abiders and otherwise increasing their prominence in community life, order-maintenance policing also increases the contact that those individuals have with one another, multiplying the opportunities they have for engaging in reciprocal interventions to protect each other's persons and property.

But how does order-maintenance policing affect the third street-crime collective-action problem - that of citizen-police cooperation? If it indeed promotes reciprocal cooperation within the public-order and communityself-policing dilemmas, then order-maintenance policing could have an indirectly positive effect on the citizen-police-cooperation dilemma as well. If fewer individuals are disposed to commit crimes, and if more neighbors are joining leagues with one another to safeguard their communities from the individuals who continue to break the law, then society need not rely nearly so heavily on severe penalties to deter crime. Less severe penalties should reduce the stigma and guilt associated with furnishing information to the police and lower the incentive that lawbreakers have to retaliate against informants. As a result, more individuals should cooperate with the police. More cooperation should, in turn, ease the pressure on police to treat citizens coercively. ${ }^{65}$

Nevertheless, order-maintenance policing poses a serious risk of aggravating the citizen-police-cooperation dilemma as well. As the police turn an increasing share of their attention to relatively minor and sometimes widespread forms of misbehavior, the number of disrespectful and possibly even violent encounters with ordinary citizens will also increase. Indeed, since the advent of order-maintenance policing in New York, complaints of police brutality in that city have risen substantially. ${ }^{66}$

There is also a risk that order-maintenance policing can become suffused with counotations of racial hierarchy and domination. Because disorderly behavior and crime are disproportionately concentrated in poor and minority neighborhoods, order-maintenance policing is likely to have a disproportionate racial impact. This effect, too, has been documented in New York. ${ }^{67}$ The perception that order-maintenance policing visits unequal burdens on minorities is likely to reinforce the disrespect that this policy connotes.

65. Of course, increased cooperation between citizens and police might generate anxiety and resentment in committed lawbreakers, who might in turn respond by putting greater pressure on citizens not to cooperate with police. Such a response, however, is likely to generate reciprocal resentment on the part of citizens toward committed lawbreakers, thereby pushing the community to cooperate even more closely with the police. This turn of events typically spells doom for gangs, the vitality of which depends heavily on community support. See JANKowSKI, supra note 46, at 202-03.

66. See Dan M. Kahan, Privatizing Criminal Law: Strategies for Private Norm Enforcement in the Inner City, 46 UCLA L. Rev. 1859, 1869 (1999).

67. See Fagan \& Davies, supra note 61 (finding racial disparities in arrest statistics). 
For all of these reasons, citizens-particularly minority ones-may grow increasingly resentful of the police and reciprocate by cooperating less. The police, whether out of fear or frustration, are then likely to behave even more coercively toward ordinary citizens. ${ }^{68}$ It is speculative, of course, to link Louima ${ }^{69}$ Diallo, ${ }^{70}$ and other notorious cases of police brutality in New York to these dynamics. But it is not particularly difficult to gauge how much goodwill the city's order-maintenance regime, at least as it was administered by the Giuliani administration, has cost the police department.

Any significant dissipation of trust between citizens and police, moreover, is likely to have a negative spillover on both the public-order and community-self-policing dilemmas. As order-maintenance policing breeds resentment and thus erodes institutional legitimacy, individuals, as moral and emotional reciprocators, will become progressively less committed to obeying the law. ${ }^{71}$ Because disobedience to law also feeds on itself, the decision of these disaffected individuals to turn to crime will induce still others to do the same. ${ }^{72}$ In the emerging climate of lawlessness, lawabiders will again react defensively by withdrawing from community life, enfeebling the sources of civic interaction that are the founts of reciprocal community self-policing. ${ }^{73}$ The result will be a self-sustaining lowcooperation, high-crime equilibrium-one that is likely to impel the adoption of even more severe penalties, further accelerating the process of norm annihilation.

The bottom line for the order-maintenance theory, then, is mixed. The reciprocity theory shows why the asserted efficacy of this policy is plausible. At the same time, however, the theory reveals why the benefits of order-maintenance could be short lived. By creating tension between citizens and the police, order-maintenance policing risks causing damage to a host of reciprocal relationships essential to holding street crime at bay.

68. See Dan Barry \& Deborah Sontag, Disrespect as Catalyst for Police Brutality, N.Y. TimeS, Nov. 19, 1997, at A1.

69. See David Kocieniewski, Injured Man Says Brooklyn Officers Tortured Him in Custody, N.Y. Times, Aug. 13, 1997, at B2 (describing sadistic and apparently racially motivated assault of Black man in police custody).

70. See Michael Cooper, Officers in Bronx Fire 4I Shots, and an Unarmed Man Is Killed, N.Y. Times, Feb. 5, 1999, at A1.

71. See generally Tyler, supra note 49 , at 385-86.

72. See Kahan, supra note 36, at 353-61.

73. See ANDERSON, supra note 42. 


\section{B. Church-Police Collaboration}

Even before the recent notoriety of the Bush Administration's "faith-based initiatives," vocated a strategic alliance between the police and the Black church. ${ }^{75}$ The Black church possesses unrivaled moral authority in the African American community $^{76}$-in no small part because of its historic opposition to police brutality. ${ }^{77}$ Accordingly, no institution occupies a better position to help the police regain legitimacy in predominantly African American inner-city neighborhoods. At the same time, few inner-city institutions have a larger stake in assisting the police to achieve their central mission. Rampant street crime not only wrecks the lives of the Black church's inner-city parishioners, but also threatens the continued participation of more prosperous, suburban parishioners, on whose patronage the church vitally depends. ${ }^{78}$

Boston is one city that has successfully exploited this convergence of interests. In the mid 1990s, for example, the Boston police department entered into an informal compact with the Ten Point Coalition ("Coalition"), an association of inner-city churches whose leaders had previously been instrumental in publicizing police abuses. ${ }^{79}$ The police agreed to give Coalition members a say in the disposition of potential offenders and to respond energetically to any episodes of police abuse identified by the Coalition. In exchange, the Coalition agreed to furnish police with information that would allow the police to remove armed gang members from the streets. ${ }^{80}$

Similarly, Chicago has successfully organized a church-police alliance of a slightly different form. On two occasions, the police and local church leaders have cosponsored massive "prayer vigils" in the city's crimeravaged south and west sides. Thousands of citizens were dispatched in

74. See generally Mary Leonard, Christian Leaders Pan Bush's Faith Plan, Boston GLoBe, Mar. 13, 2001, at A5 (describing plan of President George W. Bush to subsidize religious socialwelfare organizations and skeptical reaction to it among religious leaders).

75. I use the term "Black church" here as Mary Pattillo-McCoy does to refer "any predominantly Black congregation." Mary Pattillo-McCoy, Church Culturc as a Strategy of Action in the Black Community, 63 AM. Soc. REv. 767, 768 n.2 (1998).

76. See C. Eric Lincoln \& Lawrence H. Mamiya, The Black Church in the african AMERICAN EXPERIENCE 7-19 (1990); Pattillo-McCoy, supra note 75, at 769.

77. See Tracey L. Meares \& Dan M. Kahan, Law and (Norms of) Order in the Inner City, 32 LAW \& SOC'Y REV. 805, 828 (1998).

78. See Richard R.W. Brooks, Hold-Outs and Holymen in Bronzeville: Race, Religion and Development on Chicago's South Side 4-5 (May 4, 1999) (unpublished manuscript, on file with author). My analysis here focuses on the potentially constructive role of the Black church in combatting crime in African American communities. It is likely, however, that similar police-church collaborations would be beneficial in other minority communities, including Latino/a ones, in which the state enjoys less legitimacy than religious institutions.

79. See Jenny Berrien \& Christopher Winship, Should We Have Faith in the Churches? Ten Point Coalition's Effect on Boston's Youth Violence 14-15 (July 1999) (unpublished manuscript, on file with author).

80. See id. at 27-31. 
groups of ten to locations of open air drug markets and other prominent gang activities. Accompanied by the police, these details would sing and pray, inviting gang members to join in. Thereafter, larger groups of citizens convened in an area park for "praise celebrations" consisting of inspirational speeches, gospel music, and free food ${ }^{81}$

In both cities, the church-police strategy appears to have produced significant law-enforcement benefits. Harvard sociologist Christopher Winship and coauthor Jenny Berrien conclude that the alliance with the Ten Point Coalition not only furnished the police with a steady flow of high quality tips, but also placed the police under an "umbrella of legitimacy," shielding the department from public resistance as it targeted gang-pervaded neighborhoods for stricter enforcement of public-order provisions. ${ }^{82}$ An astonishing reversal in Boston's previously mounting youth homieide rate followed, including a two-and-a-half-year period in which the city did not experience a single juvenile gun fatality ${ }^{83}$ University of Chicago law professor Tracey Meares credits the Chicago Prayer Vigils with enhancing public satisfaction with the police and with increasing interactions among churches and civic associations more generally. These effects predict increased compliance with law under both the "legitimacy" and "social organization" theories of crime control. ${ }^{84}$

Although Berrien and Winship and Meares rely on a variety of socialnorm mechanisms, their accounts of why police-church collaborations work can readily be restated in reciprocity terms. To begin, this lawenforcement strategy can be expected to promote positive forms of reciprocity within the citizen-police-cooperation setting. When citizens observe church leaders working with the police, they develop a more favorable view of the police. In addition, where the church (as in the case of the Ten Point Coalition) acts as an intermediary, citizens face less risk in supplying relevant information to law enforcement, and have more reason to believe that supplying it will actually accomplish something. ${ }^{85}$ They also endure less stigma and guilt, not only because the church, unlike the police, is an institution of uncontested moral authority, but also because the church's role in determining the disposition of offenders helps to assure cooperating citizens that they are not exposing the individuals they report to treatment that community inembers will interpret to be arbitrary or unduly severe.

81. See Tracey L. Meares, Churches, Communities, and Crime: A Community Focused Model of Faith-Based Initiatives 17-18 (Sept. 7, 2001) (unpublished manuscript, on file with author).

82. See Berrien \& Winship, supra note 79, at I4-19, 28-39.

83. See id.

84. See Meares, supra note 81.

85. Of course, as church leaders facilitate greater cooperation between citizens and the police, relations between the church and criminal gang members may suffer. Were gang members to respond, however, by retaliating against the church, they would drive an even greater wedge between themselves and the community, a condition that is extremely perilous for the survival of gangs. See $\mathbf{J}_{\text {ANKOWSKI, }}$ supra note 46 , at $202-03$. 
For all these reasons, more individuals choose to cooperate with law enforcement.

As citizens start to cooperate more and otherwise become more favorably disposed toward the police, the police form a more positive view of members of the community. Meares's research documents that the prayer vigils, for example, had exactly this effect. ${ }^{86}$ The police are thus more disposed to treat citizens with respect in their daily encounters, both because they fear them less and because they value their goodwill more. Treated more respectfully, citizens can be expected to reciprocate by behaving even more cooperatively. ${ }^{87}$

At the same time, church-police collaboration helps to neutralize the potential of other law-enforcement functions to dissipate reciprocal cooperation between citizens and police. The goodwill imparted to the police by their association with the Black church disposes citizens to mterpret in a more positive light police action that might otherwise have generated resentment. ${ }^{88}$ Under the "umbrella of legitimacy" afforded by its compact with the Ten Point Coalition, the Boston Police Department, for example, was able to target certain neighborhoods for order-maimtenance policing without apparently provoking the resentment that the New York Police Department encountered. ${ }^{89}$ When the church is mvolved im moderating law enforcement generally, citizens are also less likely to see the occasional use of severe penalties for especially dangerous individuals as reflecting animus against minority communities, particularly if apprehension of those individuals has been facilitated by the church. ${ }^{90}$

By the same token, citizens are likely to be more forgiving of isolated instances of police misconduct. Meares, for example, is tolerant of aggressive policing and even attributes the goodwill generated by the prayer vigils with helping to abate tension after an altercation between the police and a South Side clergyman. ${ }^{91}$ Berrien and Wimship similarly discuss the role of Ten Point Coalition leaders in calming community residents during a controversial police investigation of African American gang members accused of murdering a local prosecutor. ${ }^{92}$ The Chicago and Boston departments' ability to weather these storms stands in marked contrast to the immense reputational dainage suffered by the New York Police Department in the

86. See Tracey Meares et al., Community Institutional Integration 11, 13 (Jan. 1999) (unpublished manuscript, on file with author).

87. See Tyler, supra note 49.

88. Cf. id. at 375 (finding that whether citizen perceives police behavior during an encounter in a positive light or a negative one is influenced by legitimacy of police in eyes of the citizen).

89. See Berrien \& Winship, supra note 82 , at 28-32.

90. See id.

91. See Meares, supra note 81 , at 29-30.

92. See Berrien \& Winship, supra note 82, at 33-38. 
aftermath of the Diallo and Louima cases. ${ }^{93}$ Church-police collaboration at least partially shields police legitimacy from the public-relations impact of such misbehavior, assuring that the cycle of self-reinforcing cooperation between police and citizens is not cut short by highly publicized instances of police misconduct.

Church-police collaboration should also increase reciprocal cooperation within the community-self-policing setting. The Chicago prayer vigils, in particular, brought together thousands of private citizens concerned about crime in their neighborhoods. As Meares's data show, contacts among the people who participated in the vigils continued and increased in frequency thereafter. ${ }^{94}$ Ongoing interactions among such individuals create the circumstances in which reciprocal patterns of neighborhood monitoring, mentoring, and positive street presence take root. It is also likely that many individuals who did not themselves take part in the vigils were still moved to reciprocate the conspicuous willingness of so many of their neighbors to fight neighborhood crime. ${ }^{95}$

Whatever positive effects church-police collaboration had on the citizen-police-cooperation and community-self-policing dilemmas, moreover, are likely to spill over to the public-order dilemma. As Winship and Berrien and Meares show, associating with the Black church mcreases the legitimacy of the police. Citizens predictably reciprocate legitimacy with increased compliance with the law. ${ }^{96}$ And increased compliance, through reciprocity dynamics, can be expected to generate even more of the same.

The reciprocity theory, in short, lends considerable credibility to the claimed virtues of the church-police collaboration strategy. However, it also brings into focus at least one serious concern with this New Community Policing technique. To state the obvious, United States is a religiously heterogeneous society. Even predominantly African American inner cities are not religiously homogenous. The Black church itself comprises multiple Christian denominations. It also faces ever-stiffer competition from Islam, which gains many thousands of African American converts every year. ${ }^{97}$ Even assuming (as seems reasonable) that church-police

93. See generally Jacob H. Fries, More Love the Police but Fewer Want to Join, N.Y. TIMEs, Oct. 4,2001 , at D4 (reporting that the "public image" of the New York Police Dcpartment was tarnished by "incidents like the torture of Abner Louima and the shooting death of Amadou Diallo").

94. See Mcares, supra note 81, 27-28.

95. Cf. id. at 28 (documenting positive spillover of vigils on attitudes of nonparticipants).

96. See Tyler, supra note 49.

97. See U.S. Dep't of State International Information Programs, Fact Sheet: Islam in THE UNITED STATES, at http://usinfo.state.gov/usa/islam/fact2.htm (last visited Apr. 16, 2002). Since at least the 1960s when Martin Luther King, Jr., and Malcolm X battled for political ascendancy, relations between African American Christians and African American Muslims have been tense. They have been exposed to even more strain since the terrorist attack of September 11. See, e.g., African-American Muslims Enduring Taunts, Stares, ATLANTA J.-Const., Oct. 22, 2001, available at http://www.accessatlanta.com/ajc/islam/1022localmuslims.html. 
collaboration in the form practiced in cities like Chicago and Boston does not violate the Constitution, there remains ample room for anxiety that such a policy might embroil the state im the types of religious rivalries the Establishment Clause was meant to shield it from.

This concern is not merely speculative. Meares reports that Christian ministers did indeed object to the inclusion of Muslim clerics in the planning of the Chicago prayer vigils. Anxious not to alienate the leaders of the larger Christian congregations, the police accommodated them on this issue. While some Muslim citizens did ultimately participate in the vigils, their presence was muted..$^{98}$

Should it become an occasion for tension between the adherents of rival faiths, the church-police collaboration strategy could generate forms of reciprocal distrust that would vitiate its crime-reducing potential. If, for example, the police were perceived to be sidimg with the Black church leaders in their competition with Islamic ones, Muslims would likely become resentful. Muslims would thus become less likely to join leagues in community self-policing with their Christian neighbors, who im turn would be less inclined to watch out for Muslim residents' interests. Muslims might grow less inclined to cooperate with the police, who could be expected to reciprocate by treating Muslim citizens with even less respect. State legitimacy could be compromised, diminishing Muslim citizens' commitment to obeying the law. Through negative reciprocity, more lawbreaking would likely breed more of the same. The state would be obliged to raise criminal penalties, displacing community self-policing and potentially alienating inner-city residents of all faiths. Again, the result would likely be a self-sustaining low-cooperation, high-crime equilibrium.

So under the reciprocity theory, the case for the church-police collaboration strategy is also mixed. Its potential to promote trust and reciprocal cooperation between neighbors and between citizens and police is high. But so is the risk that it will inflame religious rivalries, and thus extinguish trust among these same groups.

\section{Selective Privatization}

We are accustomed to thinking of law enforcement as an exclusive prerogative of the state. The New Community Policing invites us to think again. Another alternative to the classic deterrence strategy is the selective delegation of law enforcement and punishment functions to networks of private anti-crime associations.

Chicago has pioneered this form of community policing, too. Under CAPS-the Chicago Alternative Policing Strategy-the Chicago Police

98. Tracey L. Meares, Presentation at Yale Law School (Feb. 27, 2001); Interview with Tracey L. Meares, Professor of Law and Director of the Center for Studies in Criminal Justice, University of Chicago Law School in New Haven, Conn. (Feb. 27, 2001). 
Department divided the city's most crime-ridden neighborhoods into a collection of "advisory councils," which typically comprised no more than two or three city blocks. Each council was assigned a "beat officer," who was under strict instructions (at a time when the Mayor desperately feared a successful challenge from a minority candidate) to translate the counsel's grievances into an agenda of problems to be solved by policing strategies acceptable to community residents. ${ }^{99}$

The most acceptable strategies involved the selective privatization of a variety of law-enforcement tasks. One of these was order-maintenance policing. In events dubbed "Operation Beat Feet," "March for Peace," and "Good Guys Loitering," the advisory councils organized large numbers of law-abiding citizens to occupy the streets of disorderly neighborhoods. By engaging in "positive loitering" and anti-drug marches, these citizens transformed high-crime neighborhoods into law-abiding ones during hours when they otherwise might have been centers of criminal activity. ${ }^{100}$

CAPS also privatized criminal investigations. At advisory council "beat meetings," citizens frequently complained of sources of disorder that the police lacked the resources to investigate. When this happened, the citizens themselves were encouraged to gather the evidence necessary to obtain legal relief. Thus, on one occasion, citizens facilitated the closure of a noisy tavern, which attracted disorderly patrons, by furnishing evidence of chronic health code violations. ${ }^{101}$ On another, citizens contributed to the jailing of a slumlord, whose rundown tenement had become the site of drug dealing and gang activity, by collecting evidence of his "reckless conduct" in managing the building. ${ }^{102}$

Finally, CAPS facilitated instances of private shaming. One of these involved a two-year picketing campaign in which homeowners demonstrated outside the home of a slumlord who had allowed his properties to become the sites of deadly gang activity. The demonstrators "were fed up with the noise, crime, violence, and general unrest that stemmed from the problem buildings ... . They hoped they could make the building owner as uncomfortable in his home as he was making them in theirs."103

This form of highly participatory and decentralized law enforcement proved to be as successful as it was unorthodox. Examining crime and opinion data, criminologists Wesley Skogan and Susan Hartnett have concluded that in the neighborhoods in which CAPS operated, trust in the

99. See generally Wesley G. Skogan \& Susan M. Hartnett, Community Policing Chicago STYLE (1997).

100. See id. at 174-75, 225.

101. See id. at 166-67.

102. See id. at $175-76$.

103. Id. at $177-78$. 
police grew significantly, as did trust among neighbors. ${ }^{104}$ All forms of street crime-from drug distribution to robbery to homicide-dropped. ${ }^{105}$

The behavioral mechanisms at work can again be explained in reciprocity terms. In effect, CAPS promoted trust, and hence reciprocal cooperation, within all three of the collective-action settings that construct the problem of street crime. To begin, CAPS had a positive effect on the coinmunity-self-policing dilemma. Whereas traditional policing strategies risk displacing community self-policing, CAPS assigned highly conspicuous elements of law enforcement to community residents themselves. As they observed their neighbors attending and speaking up at council ineetings, and thereafter participating in order-maintenance demonstrations, public shamings, and the like, citizens realized that in fact their neighbors were willing to take an active role in safegnarding their community from crime. Those who formed this impression thereafter reciprocated, either by participating in CAPS initiatives or by entering into less formal arrangements to watch out for one another's interests.

The CAPS approach to community policing also helped to promote positive reciprocity within the citizen-police-cooperation setting. Citizens, long accustomed to seeing the police as simultaneously indifferent to their needs and disrespectful of their rights, now were exposed to highly responsive and solicitous officers. Unsurprisingly, citizens grew more trustful and thus more willing to cooperate with the police. In addition, CAPS made it easier to cooperate with the police by eliminating social meanings that can make such behavior an occasion for guilt or ostracism: those who took part in CAPS were not likely to view themselves or to be viewed by others as turning their fellow citizens over to an alien or occupying force; rather, they were participating in forms of self-governance visibly supported by other members of the community. The police reciprocated the citizens' greater willingness to cooperate with thein by treating citizens more respectfully, thereby generating an even greater willinguess among citizens to cooperate with the police.

Because it had these effects on the community-self-policing and citizen-police-cooperation probleins, CAPS likely had a positive effect on the public-order dilemma as well. In a climate in which they trust each other and the state more, individuals are more likely to obey the law. And through reciprocity dynamics, such obedience feeds on itself.

The selective privatization strategy achieves these positive effects, moreover, without the risks associated with the other New Community Policing techniques. Under CAPS, the citizens themselves, not the police, perforıned the order-maintenance policing. As a result, there was little likelihood that this form of law enforcement would acquire the connotations of

104. See id. at 176-77.

105. See id. at $173,223-25,227,230$. 
racial domination and hierarchy that it came to bear in New York City. Nor does selective privatization risk triggering the sorts of sectarian rivalries that church-police collaboration does: under CAPS, citizens reciprocated one another's participation in law enforcement not as members of a common faith but simply as neighbors with a common objective. The reciprocity theory explains why we should expect selective privatization to result in a self-sustaining high-cooperation, low-crime equilibrium. And it implies that this equilibrium is likely to be a stable and lasting one.

\section{IV}

\section{CONCLUSTON}

American law has been pervasively shaped (and pervasively misshaped) by a theory of collective action that is both crude and pernicious. The theory is crude because it assumes that individuals must invariably be bribed or coerced into contributing to collective goods when doing so is contrary to their material interests. It is pernicious because in seeing material incentives as the invariable answer to collective-action problems, it makes individuals much more likely to behave in the self-interested and collectively self-defeating way that the theory itself assumes. ${ }^{106}$

Criminal-law enforcement is one of the policies distorted by the conventional theory. The classic deterrence strategy counsels severe penalties to motivate compliance with the law. The imposition of such penalties, however, systematically annihilates the social norms most likely to result in widespread, voluntary compliance.

Counteracting the distorting influence of the conventional theory of collective action is the goal of the emerging literature on law and social norms. The most promising social-norms theory, I believe, is the "logic of reciprocity," which holds that most individuals can be counted on to contribute to collective goods voluntarily so long as they are assured that others are prepared to do likewise. As a result, the promotion of trust turns out to be a more reliable and efficient means of securing socially desirable behavior than does the enforcement of incentives. This behaviorally realistic theory is rich with prescriptive insight across a host of regulatory domains.

In this Essay, I have examined the relevance of reciprocity for streetlevel policing. The extent of street crime in a community, I have argued, is determined by the success of its residents in negotiating three collectiveaction dilemmas: that between individuals, relating to public order; that between neighbors, relating to community self-policing; and that between citizens and police, relating to deference and respect. Policing techniques associated with the classic deterrence theory have failed precisely because

106. See Jerry L. Mashaw, Greed, Chaos, and Governance: Using Public Choice to Improve Public LaW (1997). 
they dissipate trust, and hence inhibit reciprocal cooperation, across all three of these settings.

The techniques associated with the New Community Policing, in contrast, all work much better precisely because they foster trust and promote reciprocal cooperation. These strategies not only reflect a more realistic understanding of individual emotional and moral commitments; they also make the hope that citizens will be morally and emotionally committed to obey the law more realistic. 
